\title{
Administration of Gonadal Steroids to the Castrated Male Rat Prevents a Decrease in the Release of Gonadotropin- Releasing Hormone from the Incubated Hypothalamus
}

\author{
Robert S. Rudenstein, Homayoon Bigdeli, Maureen H. MCDonald, and \\ PETER J. SNYDER, Endocrine Section, Department of Medicine, University of \\ Pennsylvania School of Medicine, Philadelphia, Pennsylvania 19104
}

\begin{abstract}
A B S T RAC T The influence of testosterone on gonadotropin-releasing hormone (GnRH) secretion was assessed indirectly by altering the serum testosterone concentration of male rats and measuring GnRH release from their incubated hypothalami $1 \mathrm{wk}$ later.

$\mathrm{GnRH}$ release from hypothalami of castrated rats was $13.4 \pm 1.2(\mathrm{SE}) \mathrm{pg} / \mathrm{h}$, compared to $35.3 \pm 3.8 \mathrm{pg} / \mathrm{h}$ from hypothalami of intact rats $(P<0.001)$. GnRH release from the hypothalami of castrated rats treated with testosterone propionate, 100 or $500 \mu \mathrm{g}$ daily, was $25.0 \pm 3.4 \mathrm{pg} / \mathrm{h}$ and $27.9 \pm 3.6 \mathrm{pg} / \mathrm{h}$, which is significantly greater $(P<0.05$ and $P<0.01$, respectively) than that from hypothalami of castrated rats treated only with sesame oil.
\end{abstract}

A similar decrease in GnRH release from hypothalami of hypophysectomized rats and prevention of this decrease by treating the hypophysectomized rats with testosterone propionate is evidence that the observed effects of testosterone are not mediated via luteinizing hormone and(or) follicle-stimulating hormone secretion. Treatment of castrated rats with either dihydrotestosterone propionate or estradiol benzoate also prevented the decrease in $\mathrm{GnRH}$ release from the hypothalami of castrated rats.

We conclude that testosterone, dihydrotestosterone, and estradiol all prevent the decrease in GnRH release from hypothalami of castrated rats treated with these steroids. The possibility exists that these steroids may also maintain $\mathrm{GnRH}$ secretion in vivo.

\section{INTRODUCTION}

Secretion of luteinizing hormone (LH) ${ }^{1}$ and of folliclestimulating hormone (FSH) by the pituitary gland

Received for publication 21 August 1978 and in revised form 23 October 1978.

${ }^{1}$ Abbreviations used in this paper: FSH, follicle-stimulating hormone; GnRH, gonadotropin-releasing hormone; LH, luteinizing hormone. are stimulated by gonadotropin-releasing hormone (GnRH) and are inhibited by testosterone. The inhibitory effect of testosterone on GnRH-stimulated LH secretion occurs, at least in part, directly at the level of the pituitary gland, since this effect can be demonstrated with incubated pituitary glands (1) and with pituitary cell cultures $(2,3)$. Little data is currently available concerning the possible effects of testosterone and other gonadal steroids on GnRH secretion from the hypothalamus. Castration of male rats has been shown to decrease hypothalamic GnRH content, and testosterone treatment of castrated rats to prevent the decrease in GnRH content (4). These changes in hypothalamic GnRH content could reflect changes in either GnRH synthesis or secretion, or both.

The purpose of this study was to determine the effect of testosterone on GnRH secretion indirectly by altering the serum testosterone concentration of adult male rats and then measuring $\mathrm{GnRH}$ release from their incubated hypothalami. GnRH release in the hypothalamic incubation system employed here has been shown to depend on membrane depolarization and calcium uptake (6), as does the secretion of most hormones.

\section{METHODS}

Animals. Male Sprague-Dawley rats, 200-250 g, were used for all experiments. Immediately after either castration or hypophysectomy (the latter performed at Charles River Breeding Laboratories, Wilmington, Mass.), the animals were injected subcutaneously with $0.1 \mathrm{ml}$ sesame oil, either alone or with added steroid. The steroids (Steraloids, Pawling, N. Y.) included testosterone propionate, 100 or $500 \mu \mathrm{g}$; dihydrotestosterone propionate, 20 or $100 \mu \mathrm{g}$; and estradiol benzoate, $1.0 \mu \mathrm{g}$. All hypophysectomized animals also received subcutaneous injections of $250 \mu \mathrm{g}$ of hydrocortisone in sesame oil and $4.0 \mu \mathrm{g}$ of L-thyroxine in saline (7). All injections were continued daily for a total of $7 \mathrm{~d}$. On the day after the seventh injection the treated rats, and a control group of intact rats for each experiment, were sacrificed by decapitation. Trunk blood was obtained for measurement of serum LH, FSH, and testosterone. 
Incubation. Hypothalami were removed and incubated as described (6). The hypothalami were placed, one per tube, in incubation medium at $37^{\circ} \mathrm{C}$. The medium contained KrebsRinger salts, except for $2.7 \mathrm{mM} \mathrm{NaHCO}$, and also contained $20 \mathrm{mM}$ Hepes, $56 \mathrm{mM}$ glucose, Eagle's amino acids and vitamins, and $20 \mathrm{mM}$ L-glutamine. The $\mathrm{pH}$ was adjusted to 7.0.

The hypothalami were preincubated in $2 \mathrm{ml}$ medium for 30 min in a Dubnoff incubator in room air. After the preincubation, the medium was aspirated and the hypothalami were washed twice with $1 \mathrm{ml}$ incubation medium. The hypothalami were incubated in $1 \mathrm{ml}$ medium for $60 \mathrm{~min}$. The medium was then aspirated and frozen until assay of $\mathrm{GnRH}$, and the hypothalami were frozen until extraction.

Extraction of hypothalami. The hypothalami were homog-

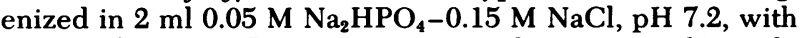
a motor-driven, Teflon (DuPont Co., Wilmington, Del.) pestle at $830 \mathrm{rpm}$. After the addition of $10 \mathrm{ml} \mathrm{95 \%} \mathrm{ethanol} \mathrm{and}$ mixing, the homogenate was centrifuged at 2,000 rpm for 15 min. The supernate was dried in a $60^{\circ} \mathrm{C}$ water bath overnight. The dried extract was kept at $-20^{\circ} \mathrm{C}$ until immediately before GnRH assay. To determine the efficiency of recovery of GnRH by this extraction procedure, 30 male Sprague-Dawley rats, $200-250 \mathrm{~g}$, were sacrificed and their hypothalami were isolated. 15 of the hypothalami were extracted in the manner above; the other 15 were extracted in a similar fashion, but $10,000 \mathrm{pg}$ synthetic $\mathrm{GnRH}$ was added before homogenization. Recovery of the exogenous $\mathrm{GnRH}$ was $88 \%$.

Assays. GnRH was assayed by a modification of the method of Nett et al. (8), with anti-GnRH generously provided by them. The modification was as described (6), except that the oxidizing agent used for the preparation of [ $\left.{ }^{125} \mathrm{I}\right]$ iodoGnRH was chloramine T ( $5 \mu \mathrm{g})$, rather than lactoperoxidase, because the stability of $\left.{ }^{125} \mathrm{I}\right]$ iodo-GnRH prepared with lactoperoxidase varied with the batch of lactoperoxidase. Binding of [125I]iodo-GnRH to anti-GnRH was optimum at $\mathrm{pH}$ 7.0-7.2; assay reagents were therefore titrated to $\mathrm{pH} 7.2$ (6). The lower limit of sensitivity of the assay was $1.5-2.0 \mathrm{pg} /$ assay tube. Since duplicate $200-\mu$ l aliquots of the $1.0-\mathrm{ml}$ incubation were assayed, the lower limit of detection of GnRH release was $7.5 \mathrm{pg} / \mathrm{h}$. The intra- and interassay coefficients of variation were 6 and $8 \%$.

Serum LH was measured by the ovine-ovine-rat LH assay described by Niswender et al. (9), with his anti-ovine LH No. 15, purified ovine LH for iodination (LER 1056-C2), and rat LH standard (RP-1) from the National Institute of Arthritis and Metabolic Diseases. The lower limit of sensitivity of this assay was 1-2 ng/assay tube, and the intra- and interassay coefficients of variation were 7 and 13\%. Serum FSH was measured by immunoassay, with reagents provided by the NIAMDD. The lower limit of sensitivity of this assay was 20 ng/assay tube, and the intra- and interassay coefficients of variation were 4 and $10 \%$. Testosterone was measured as described (1).

Statistical analyses were performed with Duncan's (11) multiple range test.

\section{RESULTS}

Castration and treatment with testosterone propionate (Table I). Hypothalami taken from male rats castrated $7 \mathrm{~d}$ earlier released significantly less $\mathrm{GnRH}$ into the medium during the $1-\mathrm{h}$ incubation than did hypothalami from a group of similar rats that had not been castrated. Hypothalami of rats that had been castrated and then given either 100 or $500 \mu \mathrm{g}$ of testosterone propionate daily for $7 \mathrm{~d}$ released significantly more GnRH into the medium than hypothalami of castrated rats and similar amounts to that released from hypothalami of intact rats. Hypothalami of castrated rats contained significantly less GnRH than those of intact rats. Treatment of castrated rats with either 100 or 500 $\mu \mathrm{g}$ of testosterone propionate daily prevented the decrease in GnRH content.

Castration caused the expected decrease in serum

TABLE I

Effects of Castration of Male Rats and Treatment with Testosterone Propionate on GnRH Release from Their Incubated Hypothalami

\begin{tabular}{|c|c|c|c|c|}
\hline & \multirow[b]{2}{*}{ Intact rats } & \multicolumn{3}{|c|}{ Castrated rats treated with } \\
\hline & & Sesame oil & $\begin{array}{c}\text { Testosterone } \\
\text { propionate, } \\
100 \mu \mathrm{g} / \mathrm{d}\end{array}$ & $\begin{array}{c}\text { Testosterone } \\
\text { propionate, } \\
500 \mu \mathrm{g} / \mathrm{d}\end{array}$ \\
\hline$n$ & 18 & 18 & 18 & 18 \\
\hline GnRH release, $p g / h$ & $35.3 \pm 3.8$ & $13.4 \pm 1.2^{*}$ & $25.0 \pm 3.4 \S$ & $27.9 \pm 3.6^{\prime \prime}$ \\
\hline GnRH content, pg/hypothalamus & $2,289 \pm 203$ & $1,420 \pm 109 \ddagger$ & $1,976 \pm 132 \S$ & $2,432 \pm 193^{1}$ \\
\hline Serum testosterone, $\mathrm{ng} / \mathrm{ml}$ & $4.5 \pm 0.5$ & $0.72 \pm 0.04^{*}$ & $2.0 \pm 0.1^{9}$ & $6.4 \pm 0.5$ \\
\hline Serum LH, $n g / m l$ & $30.8 \pm 3.3$ & $187 \pm 19.7^{*}$ & $82.1 \pm 22.1 \S$ & $7.6 \pm 0.5$ \\
\hline Serum FSH, $n g / m l$ & $244 \pm 17$ & $600 \pm 37^{*}$ & $418 \pm 53 \oint$ & $214 \pm 8$ \\
\hline
\end{tabular}

Male rats, 200-250 g, were left intact or castrated. Castrated rats were treated with either sesame oil alone or with sesame oil containing testosterone propionate, 100 or $500 \mu \mathrm{g}$ daily for $7 \mathrm{~d}$. The animals were then decapitated, and the hypothalami incubated, as described in Methods, and blood collected. Values are means $\pm \mathrm{SE}$. Statistical significance:

${ }^{*} P<0.001$ vs. intact rats.

$\ddagger P<0.01$ vs. intact rats.

$\S P<0.05$ vs. oil treated.

" $P<0.01$ vs. oil treated.

I $P<0.001$ vs. oil treated. 
TABLE II

Effects of Hypophysectomy of Male Rats and Treatment with Testosterone Propionate on GnRH Release from Their Hypothalami In Vitro

\begin{tabular}{|c|c|c|c|}
\hline & \multirow[b]{2}{*}{ Intact rats } & \multicolumn{2}{|c|}{ Hypophysectomized rats treated with } \\
\hline & & Sesame oil & $\begin{array}{c}\text { Testosterone } \\
\text { propionate, } \\
500 \mu \mathrm{g} / \mathrm{d}\end{array}$ \\
\hline$n$ & 13 & 13 & 14 \\
\hline $\begin{array}{l}\text { GnRH release, } \\
\quad p g / h\end{array}$ & $37.5 \pm 4.2$ & $20.9 \pm 1.3^{*}$ & $44.9 \pm 3.1 \S$ \\
\hline $\begin{array}{l}\text { GnRH content, } \\
\text { pg/hypo- } \\
\text { thalamus }\end{array}$ & $2,240 \pm 180$ & $1,200 \pm 80 \ddagger$ & $1,950 \pm 140 \S$ \\
\hline $\begin{array}{l}\text { Serum testos- } \\
\text { terone, } n g / m l \\
\text { Serum LH, }\end{array}$ & $3.8 \pm 0.3$ & $0.22 \pm 0.01 \ddagger$ & $8.0 \pm 0.5 \S$ \\
\hline$n g / m l$ & $24.5 \pm 3.2$ & $8.4 \pm 0.3^{*}$ & $7.8 \pm 0.2$ \\
\hline
\end{tabular}

Male rats, 200-250 g, were left intact or hypophysectomized. All hypophysectomized rats were treated with L-thyroxine and hydrocortisone (in Methods). One group of hypophysectomized rats was also given sesame oil, and the other group of hypophysectomized rats was given sesame oil with testosterone propionate, $500 \mu \mathrm{g}$ daily for $7 \mathrm{~d}$. The rats were then decapitated, and the hypothalami incubated, as described in Methods, and blood collected. Values are means \pm SE. Statistical significance:

$* P<0.01$ vs. intact rats.

$\ddagger P<0.001$ vs. intact rats.

$\S P<0.001$ vs. oil treated.

testosterone and increase in serum LH and FSH concentrations. Testosterone propionate, $100 \mu \mathrm{g}$ daily, partially maintained serum testosterone levels and partially suppressed the castration-induced rises in $\mathrm{LH}$ and FSH. The 500- $\mu$ g dose of testosterone propionate produced supraphysiologic serum testosterone levels and suppressed the serum concentrations of $\mathrm{LH}$ and FSH.

Hypophysectomy and treatment with testosterone propionate (Table II). Hypothalami isolated from rats hypophysectomized $7 \mathrm{~d}$ earlier released significantly less GnRH than did hypothalami of intact rats. Hypothalami of rats that had been hypophysectomized and treated with $500 \mu \mathrm{g}$ of testosterone propionate daily released a similar amount of $\mathrm{GnRH}$ as did hypothalami of intact rats and significantly more than hypothalami of hypophysectomized rats. Testosterone propionate treatment did not prevent the decrease in GnRH release from hypothalami of hypophysectomized rats, however, unless the testosterone was begun immediately after hypophysectomy and unless thyroxine and hydrocortisone were also given. Administration of hydrocortisone and thyroxine, without testosterone propionate, to hypophysectomized rats did not prevent the decrease in GnRH release. Hypothalamic content of GnRH was also decreased significantly by hypophysectomy, and the decrease prevented by testosterone treatment. Hypophysectomized rats had significantly lower serum LH and testosterone concentrations than did the intact rats. Testosterone propionate, $500 \mu \mathrm{g}$ daily, increased the serum testosterone concentration above that of intact rats.

Treatment with dihydrotestosterone propionate (Table III). Administration of $20 \mu \mathrm{g}$ of dihydrotestosterone propionate daily to castrated rats increased GnRH release from incubated hypothalami compared to $\mathrm{GnRH}$ release from hypothalami of castrated rats

TABLE III

Effects of Castration of Male Rats and Treatment with Dihydrotestosterone Propionate on GnRH Release from Their Hypothalami In Vitro

\begin{tabular}{|c|c|c|c|c|}
\hline & \multirow[b]{2}{*}{ Intact rats } & \multicolumn{3}{|c|}{ Castrated rats treated with } \\
\hline & & Sesame oil & $\begin{array}{c}\text { Dihydro- } \\
\text { testosterone } \\
\text { propionate, } \\
20 \mu \mathrm{g} / \mathrm{d}\end{array}$ & $\begin{array}{c}\text { Dihydro- } \\
\text { testosterone } \\
\text { propionate, } \\
100 \mu \mathrm{g} / \mathrm{d}\end{array}$ \\
\hline$n$ & 10 & 12 & 12 & 12 \\
\hline GnRH release, $p g / h$ & $30.2 \pm 4.7$ & $14.0 \pm 1.2^{*}$ & $25.9 \pm 5.1 \S$ & $38.2 \pm 4.3^{\prime \prime}$ \\
\hline GnRH content, pg/hypothalamus & $2,196 \pm 326$ & $1,102 \pm 93 \ddagger$ & $1,260 \pm 98$ & $2,167 \pm 174^{\prime \prime}$ \\
\hline Serum LH, $n g / m l$ & $23 \pm 6.4$ & $129 \pm 17$ & $57.4 \pm 20.8 \S$ & $<7.5^{\prime \prime}$ \\
\hline Serum FSH, $n g / m l$ & $228 \pm 9$ & $590 \pm 27 \ddagger$ & $659 \pm 25$ & $342 \pm 27^{\prime \prime}$ \\
\hline
\end{tabular}

The experimental procedure was similar to that described in Table I, except that dihydrotestosterone propionate, 20 or $100 \mu \mathrm{g}$, was administered instead of testosterone propionate. Values are means \pm SE. Statistical significance:

$* P<0.01$ vs. intact rats.

$\ddagger P<0.001$ vs. intact rats.

$\S P<0.05$ vs. oil treated.

" $P<0.001$ vs. oil treated. 
TABLE IV

Effects of Castration of Male Rats and Treatment with Estradiol Benzoate on GnRH Release from Their Hypothalami In Vitro

\begin{tabular}{lccc}
\hline & & \multicolumn{2}{c}{ Castrated rats treated with } \\
\cline { 3 - 4 } & Intact rats & Sesame oil & $\begin{array}{c}\text { Estradiol } \\
\text { benzoate, } \\
1 \mu \mathrm{g} / \mathrm{dl}\end{array}$ \\
\hline$n$ & 8 & 8 & 8 \\
$\begin{array}{c}\mathrm{G} \text { (nRH release, } \\
\text { pg/h }\end{array}$ & $33.3 \pm 4.0$ & $20.1 \pm 2.3^{*}$ & $43.3 \pm 5.0 \$$ \\
$\begin{array}{c}\text { GnRH content, } \\
\text { pg/hypo- } \\
\text { thalamus }\end{array}$ & $3,139 \pm 270$ & $1,410 \pm 320 \ddagger$ & $2,310 \pm 240^{\prime \prime}$ \\
$\begin{array}{c}\text { Serum LH, } \\
\text { ng/ml }\end{array}$ & $19.3 \pm 3.4$ & $145 \pm 12.0 \ddagger$ & $104.4 \pm 25.1$ \\
$\begin{array}{c}\text { Serum FSH, } \\
\text { ng/ml }\end{array}$ & $220 \pm 10$ & $636 \pm 34 \ddagger$ & $51.6 \pm 34$ \\
\hline
\end{tabular}

The experimental procedure was similar to that described in Table I, except that estradiol benzoate, $1.0 \mu \mathrm{g}$ daily, was administered instead of testosterone propionate. Values are means $\pm S E$. Statistical significance:

${ }^{*} P<0.05$ vs. intact rats.

I $P<0.001$ vs. intact rats.

$\$ P<0.001$ vs. oil treated.

" $P<0.05$ vs. oil treated.

treated only with sesame oil. Administration of 100 $\mu \mathrm{g}$ dihydrotestosterone propionate daily caused an even greater rise in $\mathrm{GnRH}$ release. The lower dihydrotestosterone dose did not affect hypothalamic GnRH content, but the higher dose resulted in maintenance of a level similar to that of intact animals. The two doses of dihydrotestosterone caused a stepwise decrease in the LH rise after castration, but only the larger dihydrotestosterone dose caused a significant decrease in FSH.

Treatment with estradiol benzoate (Table IV). Administration of $1 \mu \mathrm{g}$ of estradiol benzoate daily to castrated rats prevented the decrease in $\mathrm{GnRH}$ release from incubated hypothalami. The GnRH content of the hypothalami from the estradiol-treated castrated rats was also significantly higher than that of the castrated rats treated only with sesame oil and similar to that of intact rats. This dose of estradiol benzoate was not effective, however, in suppressing significantly the LH and $\mathrm{FSH}$ rise after castration.

\section{DISCUSSION}

Stimulation of LH and FSH secretion by GnRH and inhibition of LH and FSH secretion by testosterone has been amply demonstrated in several mammalian species. Little data are available, however, concerning the possible effect of testosterone on GnRH secretion. The reasons for the paucity of such data appear to be the apparently low concentrations of $\mathrm{GnRH}$ in peripheral blood and the difficulty in obtaining blood from the hypothalamic-hypophyseal portal circulation. Neill et al. (12) found higher GnRH concentrations in the portal blood of ovariectomized than of intact monkeys, but Carmel et al. (13) did not. Slightly higher GnRH concentrations were found in the portal blood of castrated male rats than in intact male rats (14). With a bioassay, Seyler and Reichlin (15) reported higher GnRH concentrations in the serum of men who had been castrated more than $30 \mathrm{~d}$ previously, and even higher concentrations when those men were treated with estrogen. Mortimer et al. (16) found in extracted human serum that midcycle and postmenopausal women had detectable serum GnRH levels, but men and women in other phases of the menstrual cycle did not.

In addition to these attempts at measuring GnRH secretion directly, indirect assessment of the effects of testosterone on GnRH secretion has been attempted by implantation of testosterone into the rat hypothalamus and measuring the serum LH concentration. The serum LH concentration falls after implantation of testosterone into the hypothalamus $(17,18)$, but whether this fall is a result of an action of testosterone on $\mathrm{GnRH}$ secretion or an action directly on the pituitary gland after release of testosterone into the systemic circulation (17) is difficult to ascertain.

We have recently described a hypothalamic incubation system that offers the possibility of investigating the factors that regulate $\mathrm{GnRH}$ secretion (6). GnRH release into the incubation medium in this system is linear for $1 \mathrm{~h}$; stimulated by membrane-depolarizing concentrations of potassium and ouabain; and is inhibited by omitting calcium from the incubation medium or by blocking calcium uptake with verapamil. Of particular relevence to our experiments was the demonstration that omission of calcium from the medium diminished basal, as well as stimulated, GnRH release. Although release of $\mathrm{GnRH}$ into an incubation medium cannot be equated with secretion in vivo, the demonstration that $\mathrm{GnRH}$ release in this system depends on membrane depolarization and calcium influx suggests that $\mathrm{GnRH}$ release in this system is under the control of at least some of the same physiologic factors that influence the secretion of most hormones. These considerations are especially germane to interpreting the parallel results of $\mathrm{GnRH}$ release into the incubation medium and of hypothalamic GnRH content. This parallel relationship raises the possibility that the GnRH released merely leaked out. The demonstration that $\mathrm{GnRH}$ release is under physiologic control, at least to some extent, is evidence against the possibility of leakage.

Data obtained with this hypothalamic incubation system show that GnRH release from the hypothalami of rats castrated 1 wk earlier was significantly less than 
that from hypothalami taken from a control group of intact rats. Testosterone treatment of castrated rats prevented the fall in GnRH release. These changes in GnRH release suggest that the previously demonstrated decrease in hypothalamic GnRH content after castration (4), confirmed by these studies, may have been caused by a decrease in GnRH synthesis, rather than an increase in GnRH secretion.

These changes in GnRH release also suggest the possibility that the well-documented rise in serum LH concentration after castration is the result of increased pituitary sensitivity to a less than normal concentration of GnRH. Administration of exogenous GnRH to castrated male rats has already been shown to cause a greater $\mathrm{LH}$ response than to intact rats (19). Administration of testosterone to castrated male rats for $1 \mathrm{wk}$ decreases the LH response to GnRH (17).

The possibility that the decrease in hypothalamic GnRH release and content after castration was caused by the postcastration rises in $\mathrm{LH}$ and(or) $\mathrm{FSH}$, rather than by a decrease in the serum testosterone concentration, was evaluated by lowering the serum testosterone concentration by hypophysectomy. The resulting decrease in $\mathrm{GnRH}$ release, and prevention of that decrease by the administration of testosterone, suggests that testosterone, or one of its metabolites, is responsible for the observed effects on $\mathrm{GnRH}$ release.

The demonstration that testosterone can be metabolized to dihydrotestosterone (20) and to estradiol (21) in the hypothalamus, as well as in other tissues, suggested the possibility that the stimulatory effect of testosterone on GnRH release might require the conversion of testosterone to dihydrotestosterone or estradiol. Treatment of castrated rats with either dihydrotestosterone or estradiol prevented the fall in GnRH release. The necessity of the conversion of testosterone to either of these metabolites to stimulate GnRH release, therefore, remains a theoretical possibility.

We conclude GnRH release from incubated hypothalami taken from castrated rats is less than that from intact rats, and that treatment of castrated rats for $1 \mathrm{wk}$ with testosterone or dihydrotestosterone or estradiol prevents this decrease. These data suggest the possibility that these steroids may maintain GnRH secretion in vivo.

\section{ACKNOWLEDGMENTS}

We thank Dr. Terry Nett and Dr. Gordon Niswender for generous gifts of anti-GnRH serum and antiovine LH serum, Dr. Leo E. Reichert for purified ovine LH, and the NIAMDD and National Pituitary Agency for the rat LH standard (RP-1) and all rat FSH reagents for immunoassay. We are grateful to Dr. Paul Stolley and Ms. Joan Davis for statistical advice. We also thank Ms. Janice Johnson for expert technical assistance and Ms. Elaine Paolini for preparation of this manuscript.
This study was supported by U. S. Public Health Service grant HD08555 and a grant from the Population Council.

\section{REFERENCES}

1. Schally, A. V., T. W. Redding, and A. Arimura. 1973. Effect of sex steroids on pituitary responses to LH- and FSH- releasing hormone in vitro. Endocrinology. 93: 893-902.

2. Steinberger, A., and M. Chowdhury. 1974. Effect of testosterone and estradiol on the basal and LRF-stimulated secretion of gonadotropins in pituitary cell culture. Endocrine Res. Commun. 1: 389-401.

3. Drouin, J., and F. Labrie. 1976. Selective effect of androgens on LH and FSH release in anterior pituitary cells in culture. Endocrinology. 98: 1528-1534.

4. Shin, S. H., and C. J. Howitt. 1976. Effect of testosterone on hypothalamic LH-RH content. Neuroendocrinology. 21: $165-174$.

5. Kobayashi, R. M., K. H. Lu, R. Moore, and S. S. C. Yen. 1978. Regional distribution of hypothalamic luteinizing hormone-releasing hormone in proestrous rats: effects of ovariectomy and estrogen replacement. Endocrinology. 102: 98-105.

6. Bigdeli, H., and P. J. Snyder. 1978. Gonadotropin-releasing hormone release from the rat hypothalamus: dependence on membrane depolarization and calcium influx. Endocrinology. 103: 281-286.

7. Reichlin, S., J. B. Martin, R. L. Boshans, D. S. Schalch, J. G. Pierce, and J. Bollinger. 1970. Measurement of TSH in plasma and pituitary of the rat by a radioimmunoassay utilizing bovine TSH: effect of thyroidectomy on thyroxine administration on plasma TSH levels. Endocrinology. 87: 1022-1031.

8. Nett, T. M., A. M. Akbar, G. D. Niswender, M. T. Hedlund, and W. F. White. 1973. A radioimmunoassay for gonadotropin-releasing hormone (Gn-RH) in serum. $J$. Clin. Endocrinol. Metab. 36: 880-885.

9. Niswender, G. D., A. R. Midgley, S. E. Monroe, and L. E. Reichet, Jr. 1968. Radioimmunoassay for rat luteinizing hormone with antiovine LH serum and ovine- ${ }^{131}$ I. Proc. Soc. Exp. Biol. Med. 128: 807-811.

10. Caminos-Torres, R., L. Ma, and P. J. Snyder. 1977. Gynecomastia and semen abnormalities induced by spironolactone in normal men. J. Clin. Endocrinol. Metab. 45: 255-260.

11. Duncan, D. B. 1955. Multiple range tests for correlated and heteroscedastic means. Biometrics. 13: 164-176.

12. Neill, J. D., J. M. Patton, R. A. Dailey, R. C. Tsou, and G. T. Tindall. 1977. Luteinizing hormone releasing hormone (LHRH) in pituitary stalk blood of rhesus monkeys: relationship to level of LH release. Endocrinology. 101: 430-434.

13. Carmel, P. W., S. Araki, and M. Ferin. 1976. Pituitary stalk portal blood collection in rhesus monkeys: evidence for pulsatile release of gonadotropin-releasing hormone (GnRH). Endocrinology. 99: 243-248.

14. Eskay, R. L., R. S. Mical, and J. C. Porter. 1977. Relationship between luteinizing hormone releasing hormone concentration in hypophysial portal blood and luteinizing hormone release in intact, castrated, and electrochemically-stimulated rats. Endocrinology. 100: 263270.

15. Seyler, L. E., Jr., and S. Reichlin. 1974. Feedback regulation of circulating LRF concentrations in men. J. Clin. Endocrinol. Metab. 39: 906-912.

16. Mortimer, C. H., A. S. McNeilly, L. H. Rees, P. J. Lowry, D. Gilmore, and H. G. Dobbie. 1976. Radioimmunoassay 
and chromatographic similarity of circulating endogenous gonadotropin releasing hormone and hypothalamic extracts in man. J. Clin. Endocrinol. Metab. 43: 882-888.

17. Cheung, C. Y., and J. M. Davidson. 1977. Effects of testosterone implants and hypothalamic lesions on luteinizing hormone regulation in the castrated male rat. Endocrinology. 100: 292-302.

18. Danguy, A., F. Ectors, and J. L. Pasteels. 1977. Effects of anterior hypothalamic implantation of gonadal steroids on serum and pituitary gonadotrophins (follicle-stimulating hormone and luteinizing hormone) in the castrated male rat. J. Endocrinol. 73: 105-114.
19. Debeljuk, L., J. A. Velchez-Martinez, A. Arimura, and A. V. Schally. 1974. Effect of gonadal steroids on the response to $\mathrm{LH}-\mathrm{RH}$ in intact and castrated male rats. Endocrinology. 94: 1519-1524.

20. Lieberburg, I., and B. S. McEwen. 1977. Brain cell nuclear retention of testosterone metabolites, $5 \alpha$-dihydrotestosterone and estradiol-17 $\beta$, in adult rats. Endocrinology. 100: 588-597.

21. Selmanoff, M. K., L. D. Brodkin, R. I. Weiner, and P. K. Siiteri. 1977. Aromatization and $5 \alpha$-reduction of androgens in discrete hypothalamic and limbic regions of the male and female rat. Endocrinology. 101: 841-848. 